\title{
Mandibular osteomyelitis due to Actinomyces spp
}

\author{
Nitin Gupta, ${ }^{1}$ Anivita Aggarwal, ${ }^{1}$ Prashant Ramteke, ${ }^{2}$ Manish Soneja ${ }^{1}$
}

${ }^{1}$ Department of Medicine, All India Institute of Medical Sciences, New Delhi, Delhi, India ${ }^{2}$ Department of Pathology, All India Institute of Medical Sciences, New Delhi, Delhi, India

Correspondence to Dr Manish Soneja; manishsoneja@gmail.com

Accepted 25 April 2020

Check for updates

(c) BMJ Publishing Group Limited 2020. No commercial re-use. See rights and permissions. Published by BMJ.

\begin{tabular}{l}
\hline To cite: Gupta N, \\
Aggarwal A, Ramteke P, \\
et al. BMJ Case Rep \\
2020;13:e235744. \\
doi:10.1136/bcr-2020- \\
235744 \\
\hline
\end{tabular}

\section{DESCRIPTION}

A 68-year-old hypertensive and diabetic (glycosylated haemoglobin 10\%) man presented with complaints of swelling and multiple discharging sinuses in the right jaw for 2.5 years. He was a known tobacco and areca nut chewer for last 30 years. Before the onset of these manifestations, he had a history of impacted areca nut in the right jaw, which required surgical removal. His jaw swelling was insidious in onset, painless and slowly progressive. One year into the illness, he developed discharging sinuses in the right jaw. The discharge was initially mucoid and gradually became foulsmelling and purulent. On general examination, he was found to have bilateral cervical lymphadenopathy. Local examination revealed hard woody swelling of the right jaw with multiple discharging sinuses and yellow-coloured discharge (figure 1A). Along with dental caries, ulceroproliferative lesion was also noticed inside the oral cavity (figure 1B). $\mathrm{X}$-ray of the mandible showed mandibular osteomyelitis. Histopathology of the biopsy from the sinus tract was suggestive of actinomycosis (figure 1C). He was treated with intravenous piperacillintazobactam to cover for possible anaerobic infection as the discharge was foul-smelling. He received intravenous therapy for 1 month, following which his facial swelling started to improve. He was discharged on oral amoxicillin-clavulanate and doxycycline. A follow-up after 6 months showed a significant decrease in the jaw swelling.

Cervicofacial actinomycosis is a chronic disease caused by a branching, filamentous, gram-positive bacilli belonging to the genus Actinomyces. It is characterised by progressive swelling in the jaw with a tendency to spread beyond the fascial planes. ${ }^{1}$ It is also accompanied by tissue fibrosis and multiple discharging sinuses. Cervical lymphadenopathy is seen only if the disease has progressed considerably. Osteomyelitis of the mandible is rarely seen in actinomycosis. ${ }^{2}$ Antecedent tissue injury and infection in the cervicofacial region are important risk factors of actinomycosis. ${ }^{1}$ Immunosuppressed state, including diabetes, increases the risk of actinomycosis as well. ${ }^{1}$ In this patient, impacted betel nut, poor dental hygiene and diabetes were the possible risk factors. The characteristic macroscopic and microscopic appearance of the yellow-coloured 'sulfur' granules helps to make the diagnosis of actinomycosis. Culture, although valuable, becomes negative with short courses of antibiotic therapy. ${ }^{3}$ The infection is commonly polymicrobial, and therefore, treatment should cover for other suspected organisms as well. Initial parenteral therapy (penicillin, ceftriaxone, piperacillin-tazobactam, imipenem-cilastatin) is given for a month after which patients are shifted on

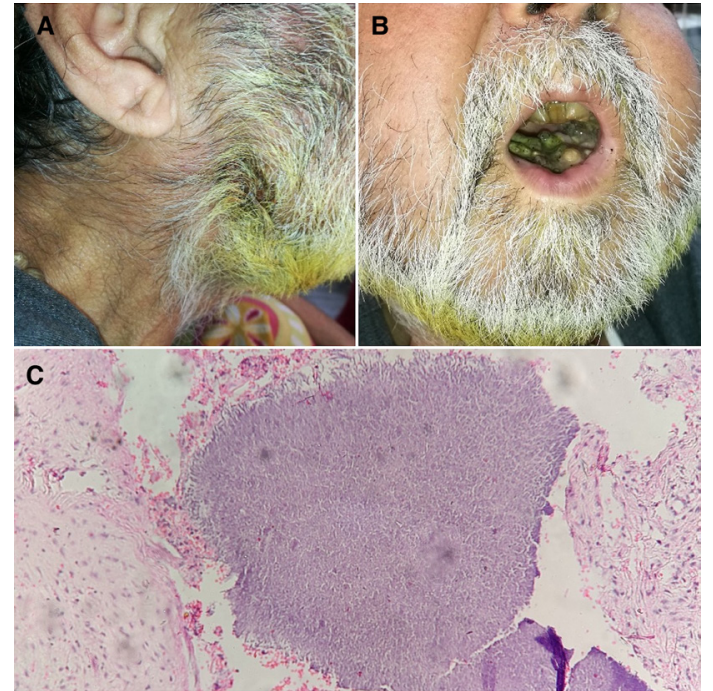

Figure 1 (A) Ulceroproliferative lesion of the right jaw with yellow coloured discharge, (B) oral proliferative lesion, (C) Histopathological examination (20x magnification) showing a clump of basophilic filamentous bacteria surrounded by acute inflammatory cells $\left(H \& E_{,}\right.$ 20x).

long-term oral therapy (oral penicillin, amoxycillin, doxycycline). ${ }^{45}$ Aggressive therapy was undertaken in this patient considering the severity of disease and possible concurrent anaerobic infection.

\section{Patient's perspective}

My illness began with a small swelling of the jaw. I ignored it in the begining but eventually it was very difficult for me to eat food. I initially tried with homeopathic medicines and local doctors but my condition did not improve. I had to come to this hospital which is more than a $1000 \mathrm{~km}$ away. I had to stay here for a month but I am happy now that the swelling and discharge have considerably reduced.

\section{Learning points}

Actinomycosis should be suspected in patients with jaw swelling and discharging sinuses (showing sulfur granules), especially with a history of trauma/infection.

- Osteomyelitis is a rare manifestation of actinomycosis and may require long-term and aggressive treatment with beta-lactams/ doxycycline. 
Contributors NG, AA and MS were involved in the clinical management of the patient. PR was involved in the laboratory diagnosis. All the authors contributed in drafting the article. NG did the review of literature and MS was responsible for overall supervision.

Funding The authors have not declared a specific grant for this research from any funding agency in the public, commercial or not-for-profit sectors.

Competing interests None declared.

Patient consent for publication Obtained.

Provenance and peer review Not commissioned; externally peer reviewed.

\section{REFERENCES}

1 Boyanova L, Kolarov R, Mateva L, et al. Actinomycosis: a frequently forgotten disease. Future Microbiol 2015;10:613-28.

2 Sasaki Y, Kaneda T, Uyeda JW, et al. Actinomycosis in the mandible: $\mathrm{CT}$ and Mr findings. AJNR Am J Neuroradiol 2014;35:390-4.

3 Gajdács M, Urbán E, Terhes G. Microbiological and Clinical Aspects of Cervicofacial Actinomyces Infections: An Overview. Dent J 2019;7:85.

4 D'Amore F, Franchini R, Moneghini L, et al. Actinomycosis of the tongue: a case report and review of literature. Antibiotics 2020;9:pii: E124:124.

5 Stájer A, Ibrahim B, Gajdács M, et al. Diagnosis and management of cervicofacial actinomycosis: lessons from two distinct clinical cases. Antibiotics 2020;9:139.

Copyright 2020 BMJ Publishing Group. All rights reserved. For permission to reuse any of this content visit

https://www.bmj.com/company/products-services/rights-and-licensing/permissions/

BMJ Case Report Fellows may re-use this article for personal use and teaching without any further permission.

Become a Fellow of BMJ Case Reports today and you can:

- Submit as many cases as you like

- Enjoy fast sympathetic peer review and rapid publication of accepted articles

- Access all the published articles

Re-use any of the published material for personal use and teaching without further permission

\section{Customer Service}

If you have any further queries about your subscription, please contact our customer services team on +44 (0) 2071111105 or via email at support@bmj.com.

Visit casereports.bmj.com for more articles like this and to become a Fellow 